\title{
Temperature and precipitation reconstruction in southern Portugal during the late Maunder Minimum (AD 1675-1715)
}

\author{
Maria-João Alcoforado, ${ }^{1}$ Maria de Fátima Nunes, ${ }^{2}$ \\ João Carlos Garcia ${ }^{3}$ and João Paulo Taborda ${ }^{4}$
}

(Centro de Estudos Geográficos, Universidade de Lisboa (FLUL), Alameda da Universidade, 1600-214 Lisboa, Portugal; ${ }^{2}$ Departamento de História, Palácio do Vimioso, Apartado 94, Universidade de Évora, 7001 Évora, Portugal; ${ }^{3}$ Departamento de Geografia, Faculdade de Letras, Universidade do Porto, Via Panorâmica, 4000 Porto, Portugal; ${ }^{4}$ Escola Secundária Gabriel Pereira, Rua Dr. Domingos Rosado, Z.urb. 3, 7000 Evora, Portugal)

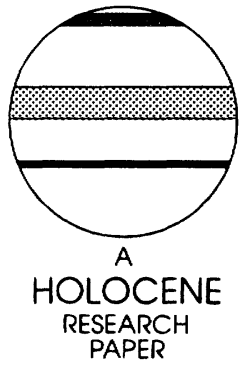

\section{Introduction}

The Maunder Minimum relates to a period of reduced solar activity between 1645 and 1715 (Eddy, 1976). Maunder himself was a superintendent at Greenwich Observatory, who discussed the effect on climatic escillations of modifications in solar spots at the end of the nineteenth century. The term Maunder Minimum has been adopted by several climatologists to characterize a period of notable European temperature decrease and marked climate variability during the 'Little Ice Age'. Mann et al. (1998) confirmed recently that a highly significant correlation had been detected between solar irradiance and the Northern Hemisphere temperature during the Maunder Minimum.

By 1994 enough information had been gathered for the reconstriction of the climate of central, western and northern Europe. There was instrumental data for Paris (Pfister and Bareiss, 1994), central England (Masley, 1974; Siegenthaler, 1994), Zürich (Plister, 1994a) and wind data for Oresund (Denmark) (Frich and
Frydendahl, 1994), as well as indexed data for Switzerland (Pfister, 1988; Pfister, 1994b), Germany (Glaser et al., 1994), Italy (Camuffo and Enzi, 1994), Bohemia and Moravia (Brazdil et al., 1994), Iceland (Ogilvie, 1995), the SE of the Iberian Peninsula (Barriendos, 1994), as well as others (see Frenzel et al., 1994).

From the available infornation, a group of climatologisis made the first synoptic interpretation of monthly weather maps for the period 1675-1704 (Wanner et al., 1994). However, data was still lacking and a conclusion could noi be drawn as to whether the 'Little Ice Age' was a period of generalized cooling in Europe and the eastern Atlantic or not.

Portugal is located in the southwestern extremity of Europe, on the boundary between the subtropical and the mid-latitude circulation regimes. Its climatic variability is related to the North Atlantic Oscillation and information about this part of Europe is necessary for the reconstruction of climate over the Europe/ North Atlantic sector (Luterbacher et al., 2000). The present research began by seeking cata in Portugal, a country with no tradition of 
historical climatology research. The most abundant information refers to Liston $\left(38^{\circ} 43^{\prime} \mathrm{N}, 9^{\circ} 09^{\prime} \mathrm{W}, 95 \mathrm{~m}\right)$ and to Evora $\left(38^{\circ} 34^{\prime} \mathrm{N}\right.$, $7^{\circ} 54^{\prime} \mathrm{W}, 309 \mathrm{~m} ; 140 \mathrm{~km}$ east of Lisbon and which has a slightly more continental Mediterranean climate). The main sources used for climate reconstruction in southern Portugal are described in the first section of this paper. In the second part, temperature and precipitation evolution in southern Portugal are presented and synoptically interpreted.

\section{Documentary sources}

Instrumental data are extremely rare for the late seventeenth and early eighteenth centuries (Bradley and Jones, 1995); so reliable documentary sources had to be used instead. In the case of Portugal, research focused on diaries, as well as on ecclesiastical, Misericórilas and municipal institutional sources.

\section{The diary of Manuel de Almeida}

The most interesting diary found was the volume of the Memorias Históricas de lisboa. written by a certain Manuel de Almeida between 7 November 1696 and 2 April 1716, and edited by Antonio Pina Cabral in 1948. Manuel de Almeida has not been jdentified hecause his name is very common. The only thing we do know is that he was a layman. The account is organized chronologically and, although non-meteorological news is the main thread throughout it, there are detailed descriptions of weather and of what Manuel de Almeida perceived to be its consequences. The fact that these descriptions may have been exaggerated was borne in mind during the analysis. In some cases, the author explicitly states his own doubts about dates - for instance: 'it snowed in Lisbon on the 12th (or 13th?) of March 1684'. This fact only lencis itself to making this document trustworthy and it will be now critically analysed since it constitutes, at the present moment, one of our best sources.

\section{Reported events}

All the information is qualitative in nature, and therefore subjective. The author mentions either short extreme weather events or writes about the weather for some months or parts of months. Data on individual days, although interesting in themselves, were not used for the inonthly reconstruction of the climate. The intensity of certain episocies, especially heavy rainfalls, may be assessed through their consequences, which at times are ciescribed in great detail.

\section{Selection criteria}

The text highlights the periods before and after the days in which noteworthy events take place, according to the author: important dates concerning the royal family, such as royal births, christenings, weddings, funerals or digressions, the arrival and departure of fieets to and fiom Brazil, battles, autos-de-fé, fires, murders and religious festivities. The only climatic-hydrologic facts that deserve mention in themselves are the floods, largely urban. The inflated prices of staple foods, which Manuel de Almeida associates with the inclemency of the weather, occasionally deserve his attention.

The selection of facts depends on the date of writing. The author starts writing in 1696 , and briefiy describes events back to 1680 with the help of some scattered notes. This first part is more concise, featuring an average of 36 lines per year between 1680

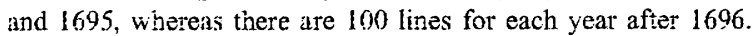

\section{Monthly variability of the available information}

Information is very unequally distributed thioughout each year, and more frequent in the winter months, particularly January, for the following reasons: (a) each yearly chronicle opens with an account of the weather concitions at the outset of each year; (b) there would, in fact, have been several extremely cold months of January during the period covered in the text. In contrast, there is much less information about summers. During these 37 years, there is information about only eight summers against 25 winters.

\section{Other individual sources}

Some other individual (and not institutional) sources have also been used. Most of them consist of manuseripts written by members of the educated class of that period and are related to social, cultural and meteorological events. The writings of José Soares da Silva and the priest João Baptista de Castro were examined.

J.S. da Silva was a member of the Royal Academy of History. Approximately every fortright between 1701 and 1716, he wrote his 'Gazette written in the form of a letter' (Gazeta composta em forma de carta), which often included information about extreme weather events or meteorological characteristics of a period (manuscript; Silva, 1931). J.B. Castro studied in a Jesuit school and for some time he lived in Rome, where he worked for Pope Clement XIII. When he returned to Portugal, he organized a Chronological Opuscule (Oprisculo chronologico), in which he wrote on important events in Portugal every year. Meteorological news about 1704 and 1709 was found in this inanuscript.

\section{Ecclesiastical sources}

\section{Pro-pluvia and pro-serenitate rogation ceremonies}

Droughts and excessive precipitation, the latter in the form of rainfall of devastating proportions or of excessive year-long humidity, were prior to the nineteenth century in most parts of Europe taken as God's punishment. His forgiveness had therefore to be sought by means of various religious tites, individual as well as collective. In Spain, pro-plivia processions were common, organized by the local ecclesiastical authorities and funced by civil authorities, the Town Halls in particular. The systematic use of the Minutes of the Chapter Edicts (Acordâos do Cabido) allowed Barriendos (1997) to reconstruct the chief drought episodes between the fifteenth and nineteenth centuries for several Spanish cities.

In Portugal, however, the rogation ceremonies that deserved written notice were rare during the L.MM. Only four references were found. Two pro-pluvia ceremonies were recorded: one of them in 1694 with supplications for an end to a drought that had lasted a year and another one at the end of the winter 1712. The pro-serenitate ceremonies took place in 1684 and 1708 . Ongoing research has revealed that rogation ceremonies were carried out more frequently during the second half of the eighteenth century.

\section{Other sources about weather phenomena}

Tite most useful information found in ecclesiastical news refers to periods of excessive rainfall when religious events, such as processions, had to be postponed. In Evora there are numerous references to rainy spells in January, mostly with regards to the procession on St Sebastian's day (20 January) and sometimes previous and following weeks. The 'weather' was important whenever it hindered the regular course of routine religious ceremonies, and this is the reason why it is mentioned at all in several ecclesiastical documents. For the LMM period, however, only two observations were found among the Minutes of the Chapter Edicts (Acordãos do Cabido) and from the Book of Memoirs and Records (Livro de Lembranças e Assentos), both from Évora.

\section{Misericórdias sources}

The Misericordias were charitable institutions founded in the sixteenth century in Portugal by Queen Leonor (wife of Manuel I) at the time of the discoveries. They were set up in many towns and organized into brotherhoods (confrarias - groups of religious 
or secular Christians) with the aim of giving spititual and material support to the local people. Each Misericórdia had its own church. All sort of important records were gathered in the Books of Minutes and Recollections (Livros de Actas e Lembranças): religious festivities organized by each confraria, food distribution, health care, etc. Weather information was sometimes appended to the description of the Misericordia activities, and diata referring to 1704 and from 1710 to 1715 was used.

\section{Municipal sources}

Several references to 'weather conditions' were found in municipal sources. The minutes of the Lisbon and Evora town halls (Actas das Camaras Municipais) were used. As climatic paroxysins triggered the implementation of a number of measures aimed at attenuating their respective consequences, these sources have proved to be quite useful. Information about water shortage or poor-quality water, insufficient wheat production and decrease of milk or meat production was found in the Evora Town Hall minutes. In the Lisbon documents no weather-related information has been found for the Late Maunder Minimum. The information from Evora was carefully analysed and compared with the wellknown historical facts. Reports on economic and social measures taken were used whenever its climatic causes were explicitly stated. When Portugal took part in the War of the Spanish Succession between 1705 and 1715, there was no wheat in Evora hecause most of it was sent to the battlefront, and consequently no data was extracted from the Evora Town Hall minutes for this period.

\section{Methods}

\section{Climatic reconstruction}

In order to reconstruct the climate during the LMM, we chose to adapt the methodology developed by Pfister $(1988 ; 1995)$ and used by other researchers such as Barriendos (1994) and Glaser (1996). Each month was given an index according to available information. If sufficient proxy information (in a quantitative forn) is available, the value of the indices concerning temperature and precipitation varies between a maximum deficit for a particular phetomenon (-3) and a maximum surfeit $(-3)$, with the value 0 corresponding to months regarded as 'normal'. Index seiting is a rather delicate task which, in the present case. depended on the intensity of the depicted consequences (qualitative information). Therefore, only the indices +1 (high temperature or henvy rainfalls) and -1 (cold weather or irought episode) were assigned to each month. Wher combined, these yield to seasonal values ranging from +3 to -3 and to annual indices from +12 to 12. The value 0 refers either to indications of normal conditions or absence of information. The lack of information very often means that the month was a normal one in view of the fact that the weather was not considered something to write about. However, it cannot be concluded that all the months for which no information exists were normal ones.

The indices were set independently for Lisbon (1680-1716) and Evora (1675-1715). On the basis of present-day climatic variability (Alcoforado, 1984; Maheras et al., 1994) and through comparison of the 17 months for which there was parallel information for Lisbon and for Evora, an index was developed for southern Portugal based on the joint data for the two cities.

\section{Available data}

The detail of the monthly information, which was used for climate reconstruction is obviously not always the same. Some examples are given in Table 1. As can be noted, even one single source may give sufficient direct information concerning a month or several weeks. For the period $1675-1715$, there are observations con- cerning hydric phenomena in $33 \%$ of the 480 months. From those, $8.3 .8 \%$ of the data was obtained from one source, $15.2 \%$ from two different sources and $1 \%$ from three sources. When more than one source was available, no contradictions were found except on two occasions. In this case no information was considered. Out of the total set of months, $20 \%$ provide thermal data. In this case the only source of direct information was the diary of Manuel de Almeida (in Cabral, 1948). If we consider winter separately, then thermal data for $35 \%$ of the months is available.

Precipitation cata is therefore more reliable, although interesting thermal information was extracted.

\section{Temperature and precipitation reconstruction between $\mathrm{AD} 1675$ and 1715}

\section{Temperature}

The results for the LMM were compared with a recent reference period 1961-90. For this reference period, months were assigned $\cdots 1$ index, when their temperature and/or precipitation value was inferior to the mean -1 standard deviation. +1 corresponds to values superior to the mean +1 standard deviation.

With regard to the annual temperature index, there is a large difference between the percentage of 'normal' montis between the LMM (81\%) and the reference period 1961-90 (53\%). We may therefore suppose that a lot of information is lacking and it is advisable not to draw any conclusions (Figure 1, right).

If, on the other hand, we consider winter (Figure 1, left) then there is only a $14 \%$ difference in the percentages of 'normal' months $(67 \%$ for the LMM and $53 \%$ for 1961-90). In this case, we may analyse the graph and concluce that the L.MM was colder: $28 \%$ of cold months during the LMM, against only $7 \%$ during the recent period. As stated before, most of the information we possess refers to cold winters (17 out of 40 ). Only for two years (out of 40) did we find references to mild winters (1699 and 1707; Figure 3). On the other hand, there is a higher percentage of 'warmer' months during the $1961-90$ period than during the LMM (Figure 1).

Another fact that may confirm that there were very cold spells during the L.MM is related to the presence of snowfall. In the 37 years spanned by the diary of Manuel de Almeida, snowfall in Lisbon is reported eight times (December 1680; January 1693, 1703, 1704, 1709, 1716; March 1684; April 1699) which shows a clear difference in relation to present conditions (only two snowfalls during the last 40 years, both in February 1954), and suggests that the 'feeling' of coldness, as expressed by the author, may be bue to lower temperatures than those registered today, as well as to different syontical patterns or higher frequency of circulation types that occur nowadays (Luterbacher, 1998). On 1 February 1954, for example, it snowed in Lisbon when there was a deep depression, centred at the east of the Iberian Peninsula; it was associated with a meridional circulation pattern (up to $500 \mathrm{hPa}$ ) and advention of a very cold and relatively unstable airmass. This particular synoptical situation will not be visible on the mean monthly pressure pattern reconstruction (Luterbacher $e t a l$, in ADVICE Final Report, 1998; Luterbacher et al., 2000), because the snow spells never lasted a sufficiently long time.

According to our sources, the 1680 s were 'normal' except for the cold winters of 1681 and 1688 (Figure 2). Unlike other places in Europe, the years 1683/84 and 1684/85 were not particularly cold (or information is lacking). Nevertheless, there were some very severe cold spells in the 1690 s (winters in 1692/93 and 1693/94; and springs in 1694 and 1698; Figure 3). According to Font Tullot (1988), this decade was the coldest of the 'Little Ice Age' in Spain. For this country, the severe winter of $1693 / 94$ is mentioned by the aforementioned source, by Matute y Gaviria 
Table 1 Listing of available data relative to four of the studied months

1 source: January 1703

Precipitation index: +1 ; temperature index: $\cdots 1$

1-20: cold weather, rain and snow; NW wind; 20-25: no rain. 25-31: cold and rain again, numerous floods (Aimeida, in Cabral, 1948)

2 sources: January 1694

Precipitation index: $\cdots 1$; temperature index: -1

It was extremely cold in December 1693 and the weather was very cold and dry during the following year. It did not rain between mid-Desember 1693 and June 1694. The harvests were very poor and the people were hungry. In Aprii and the following months, several rogation ceremonies took place in Lisbon (M. Almeida, in Cabra!, 1948: 30-32). The spring dryness is confirmed in the Municipal sources of Evera, and the lack of winter rain may be inferred (Acias da Cúmara Municipal de Évora, Vol. XXVII, Folio 11, 28/5/1694).

\section{3 sources: January and February 1708}

Precipitation indices: +1 ; no temperature indices

In Lisbon. there was no day without rain in January. In February and March it rained even more (Aimeida, in Cabral, 1948: 65-66). From mid-December unt: the end of lantsary it rained nearly every tay and thete were very frequent and intense lloods, causing several damages (Silva, manuseript, 15 February 1708). Heavy rains continued to fall in February and March, causing numerous floods (Silva, manuscript, 20 and 29 February 1708 ). On 20) Pebruary, it was decided that special prayers to God should be made on account of the heavy rains in Évora (Codices Eborensis Capituli 14 VI).

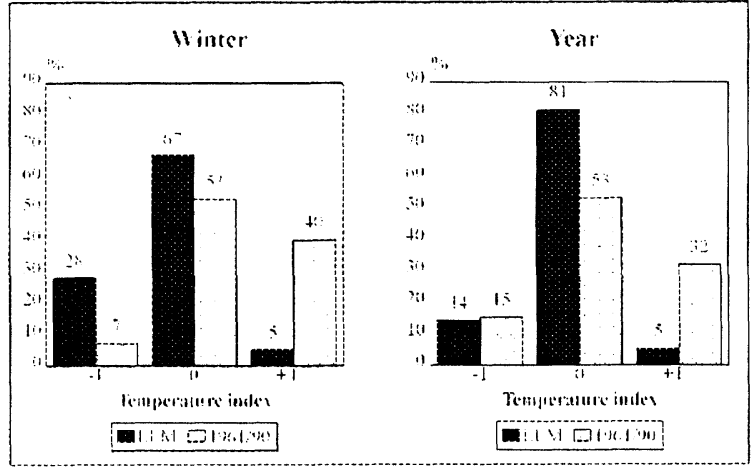

Figure 1 Temperature indices referring to the LMM and $1961-90$ (southern Portugai).

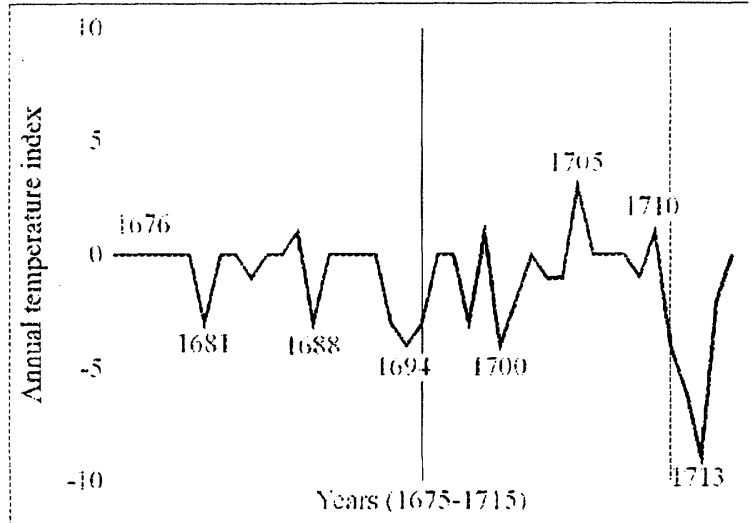

Figure 2 Annual temperature index for southern Portugal between 1675 and 1715 (see text for details).

(1886) and by Rodrigo (1996). According to Camuffo and Enzi (1994: 246), 1694 was a cold winter, but not one of the most severe in northern Iialy, and the Venetian lagoons did not freeze (Camuffo, 1987).

The pressure patterns reconstruction (Luterbacher et al., In ADVICE Final Report, 1998; Luterbacher et al.. 2000) showed that during the JMM the air pressure was fiequently higher over NE Scandinavia, particularly in winter. This fact led to advection of cold and dry air towards central and southern Europe. The findings with regard to Portugal show that this cold advection also reached the most southwesterly parts of Europe. A good example

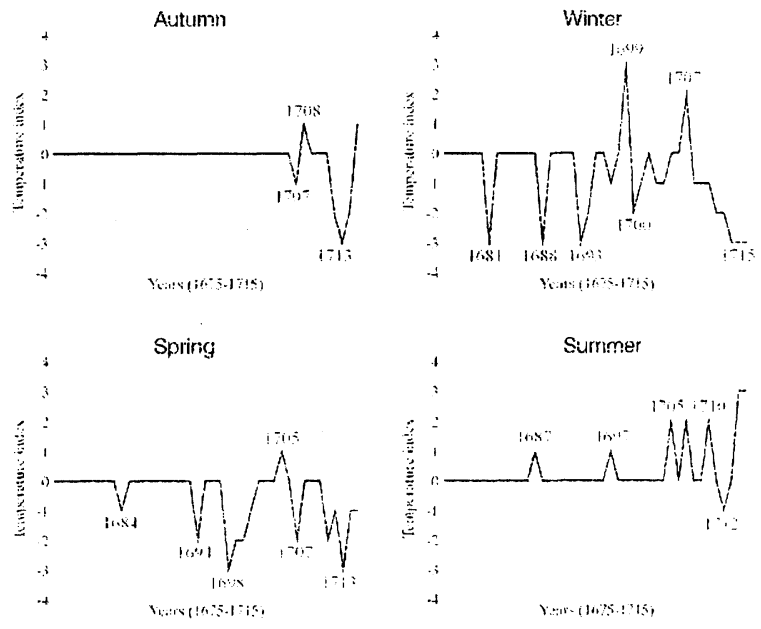

Figure 3 Seasonal temperature index for southern Portugal between 1675 and 1715 (autumn $=$ September-November; winter $=$ DecemberFebruary, etc.).

of this occurred in January and February 1694, when an anticyclone centred over the Atlantic but spread over northern Europe causing NE flux towards southwestern Europe (this was a very dry period as well).

The main differences between Portugal and central Europe in winter exist towards the end of the LMM. After 1700, the cold period continued in Portugal, especially in 1700 and between 1711 and 1715 , while further north and east the temperaiure rose (with the exception of 1709). According to pressure pattern reconstruction (Luterbacher er al., in. ADVICE Final Report, 1998; Luterbacher et al.,2000), in some of the months (such as November 1707), an Atlantic anticyclone spread over Europe at the latitude of Portugal originating a continental easteri flow towards Portugal. Simultaneously a westerly air-flow occurred in western and northern Europe, causing relatively mild winters.

The coolest period of the LMM occurred earlier in central Europe (1690s) than in eastern Europe (beginning of the eighteenth century) (Pfister, 1994a: 296). In southwestern Europe the coldest period would have also occurred at the beginning of the eighteenth century. The winter temperature decrease in Portugal, particularly at the end of the LMM, is comparable with the one referred to by Serre-Bachet (1994: 271) at grid point $35^{\circ} \mathrm{N}-10^{\circ} \mathrm{W}$ (southwestwards from Portugal), "where the cooling is recorded only from 1703'. Thus it seems that in southern Europe the greatest similarities occurred in places at the same longitude. More 


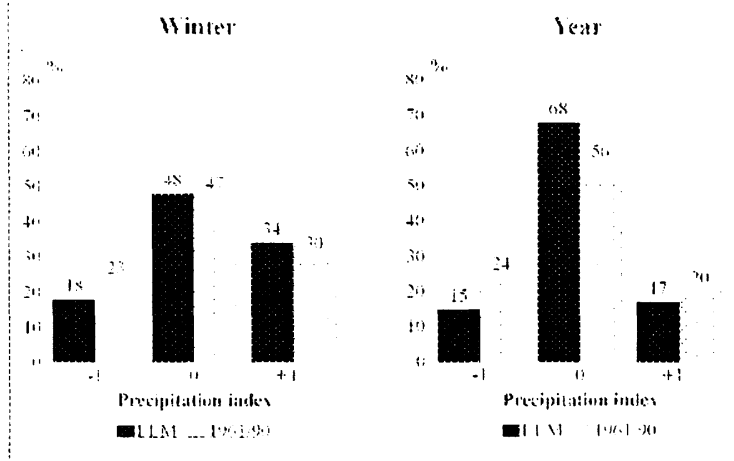

Figure 4 Precipitation indices referring to the LMSM and 1961-90 (southern Portugai).

evidence is necessary to prove this, but we can suppose that even small longitude variations highly contributed to explain climate variability in southern Europe, owing to frequent meridional circulation.

During the I.MM summers, a negative pressure anomaly occurreci over the British. Isles (Luterbacher, 1998; Luterbacher ef al., 2000). That means that strong westerlies were blowing towards western Europe, where low summer temperatures occurred. In southem Portugal there is hardly any recorded news about cool summer months (only June 1712) or about very hot summers, except: 1687 and 1697 (one hot month per year); 1705, 1707 and 1710 (iwo months per year); 1714 and 1715 (three hot montis both years). During most of the LMM period, the limit of the perturbated western circulation might have been located nothwards of the Iberian Peninsula, which could have been "protected' by the Azores Anticyclone. During the two very long-lasting 1714 and 1715 suminers, advection fiom the $E$ and SE may have occuried.

\section{Precipitation}

There is more information relative to rainfall than temperature during the L.MM. In this case, however, no large differences were found between the frequencies of dry and wet months between the two periods, as can be seen in Figure 4. In southern Portugal, the L.MM was characterized by a great precipitation variability (Figure 5), as was the case in the eighteenth and early inineteenth centuries (Alcoforado et al., 1997; and ongoing research) and during the subsequent instrumental period (Alcoforado, 1984).

Mosi of the winter months were wet or 'normal', excepi 1681 , 1689,1693 and 1694 , as well as the last winters of the LMM:

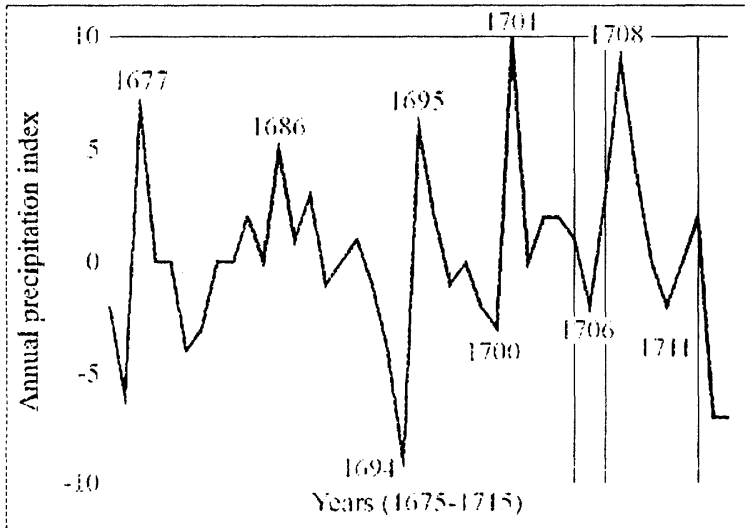

Figure 5 Annual precipitation index for southern Portugal between 1675 and 1715 (see text for details).
1711-12 and 1714-1715 (Figure 6). Nowadays the precipitation variability in Listron is more dependent on the duration of the rainy season, i.e., rainfall in spring and autumn, than on rain intensity in winter (Alcoforado, 1984). That was also the case during the LMM. Hardly any information was found relating to the autuinn in the first 15 years of the LMM, but after the drought of 1694 great interannual variability took place in autumn, with rainfall deficit periods also in $1697,1700,1707$ and 1714-15. In spring, dry seasons were found to have occurred at the beginning of the series $(1676,1680)$, in 1694 , in 1698 and at the end of the period.

According to our sources, there were frequent drought periods that occurred simultaneously with cold spells, in winter and early spring. Their synoptic causes are presented above.

If a winter drought continued into spring. then the consequences in agriculture and water shortage became significart. In 1694 , the drought lasted from January 1693 until October 1694 (shortly interrupted by a 'normal' autumn in 1693) and there were rogation ceremonies in Lisbon. There can be no doubt of the water shortage. This drought occurred all over Portugal and in central and southern Spain (Toledo and Sevilla; Barriendos, 1997). In Italy there is reference to a dry year (Camuffo and Enzi, 1994: 246). The other long droughts of the LMM in Portugal were between March and June 1680, winter 1681, spring 1698, spring 1699 , spring and autumis 1700, winter 1712 and between January 1714 and January 1716 (Figure 6). For a great part of the year 1714, the drought stretched from Portugal to Italy and to the eastern Mediterranean (Font Tullot, 1988; Barriendos, 1997; Camuffo and Enzi, 1994; Grove and Conterio, 1994).

In Portugal, summer is normally a dry season (1931-60 mean precipitation in Lisbon in July was $3.1 \mathrm{~mm}$, and in August $4.3 \mathrm{~mm}$ ). With only one exception in 1701 (Figure 6), no LMM summer rainfall excess is indicated in our sources; this was not the case further north in Europe. The reason is the same as the aforementioned one, which explains why temperatures were not particularly low: the westerlies do not seem to have affected Portugal in the summer. No precipitation deficit was inferred because of the lack of rain in July and August, as this is usial in southem Portugal.

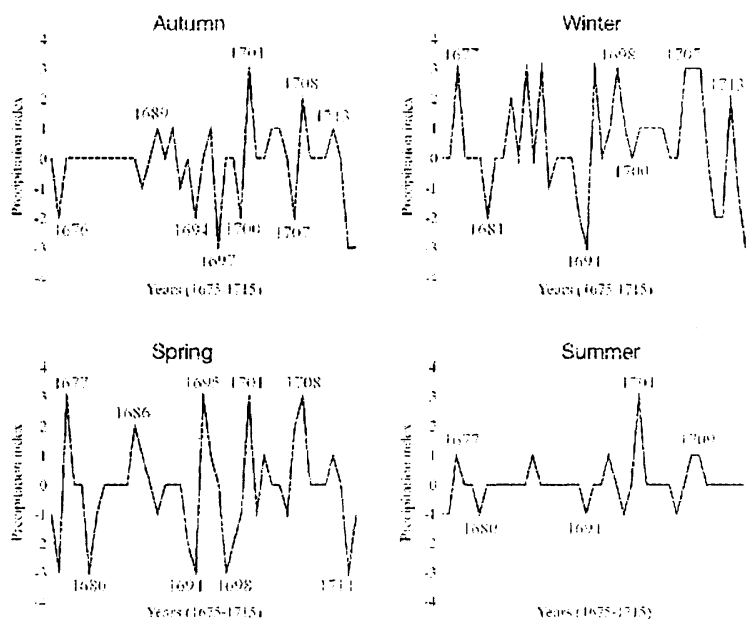

Figure 6 Seasonal precipitation index for southern Portugal between 1675 and 1715. (autumn = September-November; winter = December-Febri:ary; etc.). 


\section{Discussion}

The scarcity (or the absence of continuity) of data referring to the LMM from the different countries of the Mediterranean does not yet permit us to analyse quantitatively and systematically the main differences between them, as was done in a recent study where temperatures from Lisbon. Barcelona, Florence, Malta, Athens, and Jerusalem (1\$60-1990) were compared in order to identify anomalously warm and cold months in the Mediterranean basin (Maheras et al., 2000). The spatial distribution of the positive and negative thermal anomalies were explained in the light of the different circulation patterns in this area.

Nevertheless, on the hasis of available information (Camuffo, 1987; Camuffo and Enzi, 1994; 1995; Le Roy Ladurie, 1983; Grove and Conterio, 1994; Barriendos, 1997; Serre-Bachet, 1994; Serre-Bachet et al., 1995), we may state that hot months or cold months on the one hand, and dry or humid months on the other, did not often coincide from the Iberian Peninsula to Italy, and even less so to Greece, during the LMM.

Meridional circulation originates normally greater weather differences within the Mediterranean thas zonal circulation; but wave amplitude governs temperature and precipitation spatial variability. For example, in March 1700, according to sea-level pressure reconstruction (Luterbacher et al., in ADVICE Final Report. 1998; Luterbacher et al., 2000), a surface anticyclone produced a drought in Portugal and Spain (Barcelona, Girona and Toledo annual values in Barriendos, 1997), while a deep surface depression induced heavy rainfall in northern Italy (Camufio and Enzi, 1994: 246-47). It probibly also rained in southern France. becalsse Grove and Conterio (1994) state that the olive production was spoiled and Le Roy Ladurie (1983) writes that the vine harvest was six days late. Northeasterly airflow caused cold weather and snowfall in the eastern Mediterranean, including a great deal of snow in Crete (Grove and Conterio, 1994).

Zonal circulation is more prone to originate weather similarities within the Mediteranean. By westen circulation, rainy weather occurs in Portugal and Spain, sometimes also in southem France and Italy. Winter temperatures will then he high all over the Medjterranean (Maheras et al., 2000). Eastern circulation often generates dry weather, cold in winter and hot in summer. Maheras et al. (2000) verified that in winter when the cold air, proceeding from northeast Europe, moves along the southern flank of a large anticyclone oriented $\mathrm{E}-\mathrm{W}$, from Jerusalem to Lisbon, then negative thermal deviations to the mean occur all over the Mediterranean (Maheras et al., 2000: Figure 11b). In January 1714, a somewhat similar situation may have occurred, as confirmed by sea-level pressure reconstruction (Luterbacher et at., in ADVICE Final Report, 1998). Cold weather and drought were recorded for Portugal, nothern Spain (data for 1714 as a whole in Barriendos, 1997) and eastern Mediterraneari. This was possibly the most severe and widespread winter drought (...) affecting the whole region from central and southern. Greece to the Black sea area' (Grove and Conterio, 1994: 275). The presence of a blocking high covering large areas of Europe explains that the drought was also recorded in Bohemia and Moravia (Brazdil et al., 1994), England (Siegenthaler, 1994), Germany (Glaser et al., 1994) and Switzerland (Ptister, 1994b)

January 1709 is a month which deserves further study, as it was extremely cold in a large part of western and central Europe (Pfister et al, 1994). 'In many parts of Europe this may have been the coldest winter month within the last five hundred years' (Pfister et al., 1994: 345). January 1709 was also extremely cold in the western and central Mediterranean: there is evidence referring to Lisbon, Seville (Palomo, 1984), Girona (manuscript from Constans), southern France (Le Roy Ladurie, 1983), northern Italy (Camufto, 1987; Camuffo and Enzi, 1994: 246-47) and former Yugoslavia. The lagoons of Venice and the river at Girona froze and allowed the crossing of people (Girona) and of cartiages and artillery (Venice). Palomo writes about an 'unusually cold winter' in Seville. It snowed in Lisbon, Girona and Venice. The cold paroxysm took place during the first decade of January. Lachiver (1991, quoted by Pfister et al, 1994) writes that the advection of Arctic air progressed across France, from north to south, from 5 to 7 January. These results tie in with our sources, where it is clear that the cold wave began on the 6th in Venice and southern France, on the 7th in Girona and on the 8th in Lisbon, showing that the cold airmass also progressed across the Pyrenees. The cold wave lasted three weeks in Portugal, Catalonia, France and not thern Italy.

We may suppose there was a large planetary ridge on the Atlantic, giving rise along its eastern border to northerly for northeasterly) winds in western Europe (including western and central Mediterranean areas). This interpretation is partially supported by the surface pressure reconstruction for January 1709 (Luterbacher et al., in ADVICE Final Report, 1998) in which there is also a low over central Italy (and probably a valley on the upper levels of the troposphere). This would explain the instability which gave rise to snowfall. However, as the weather was not homogeneous throughout the whole month, a more detailed pressure reconstruction will be necessary to fully understand this cold wave, which does not seem to have progressed further east. According to Grove and Conterio (1994), there is no evidence of cold weather in the eastern Mediterranean and more specifically in Greece in January 1709.

In February and March, neither very cold weather nor silow were reported in Portugal, unlike further north in Europe and Italy where all the winter months were very cold and snowy (Camuffo and Enzi, 1994: 246). This was probably due to a different relative position of the anticyclone over the Atlantic and the direction of the airflow, that arrived from the west in Portugal, according to the surface pressure reconsiruction (Luterbaciter et al., in ADVICE Final Report, 1998). However, as stated above, these maps represent monthly means and a study based on daily data would be very interesting, considering that this period represents a very cold spell during the already warmer period in nothern Europe (Glaser et al., 1994).

\section{Conclusion}

The LMM was rather a cold period in Portugal at least after 1693 and particularly in winter and spring. During the $1690 \mathrm{~s}$ the cold spells coincided with those of central, western and southern Europe, when surong high-pressure centres occuired over northern Europe. In the early 1700 s, when temperature was already rising in other places, such as England (Manley, 1974) and central Europe (Pfister, 1994a), there were still some very cold winter months in southern Portugal (with relation to Portuguese standards). The early 1700 s also represent the coldest period at grid point $35^{\circ} \mathrm{N}-$ $10^{\circ} \mathrm{W}$, southwestwards from the Algarve (Serre-Bachet, 1994). Some of the cold months in Portugal occurred during westerly circulation in central Europe, northwards from an anticyclone which originated cold eastern air flow towards the Iberian Peninsula. However, the lack of data for a longer period does not permit us to state whether the LMM cooling in southern Europe was exceptional or not. According to Serre-Bachet (1994), 'as far as these reconstructions, mainly based on tree-rings, are reliable (. . .), the Mauncier Minimum cooling was not exceptional in comparison with other cool episodes' (p. 273).

Precipitation interannual variability is similar to the present oile. Even during the present decade, very dry years have alternated with others with excessive rainfall (1996-97 and 1997-98). Rogation ceremonies were a rarity during the LMM, and their number increased during the eighteenth century (Taborda, oral 
information) which confirms the 'normality' of precipitation interarnual variability of the LMM. Subsequent to heavy rains, great material damages and even loss of life in the LMM are referred to in our sources. Nowadays, the consequences of heavy rainfalls in Portugal seem to be getting worse and worse; but this is also due to the human choice of land use (construction near or in -.. dry valleys, river channelling, deforestation). In November 1997. there were deaths and severe damage in the Alentejo (the region where Évora is located) due to flash floods, with a recurrence period of 50 or 100 years and subsequently forgotten by the following generations. However, those extreme weather events are a normal characteristic of a Mediterranean climate and cannot be directly attributed to 'global climate change'.

The latitudinal influence and the consequent exposure to western circulation (either anticyclonical or pertubated) or enstern airflux is not the only key to explain the similarities or differences in thermal or hygric excesses within the Mediterranean area. The present study and Maheras et al. (2000) confurm that 'the interest lies in the discontinuty of climatic conditions in the two halves of the Mediterranean basin' (Grove and Conterio, 1994: 284), but they also show that spatial variability is more nuanced than that, given that meridional circulation is responsible for greater spatial weather differences than just east-west contrasts. More data and joint reseatch will be necessary in order to achieve an understandirig of climate teleconnections within the Mediterranean area as well as of its historical climate change.

\section{Acknowledgements}

The sudy was carried out with the support of the ADVICE project (CE ENV4-CT95-0129-PI 951090). The authors are particulatly indabted to Professor Heinz. Wanner, who suggested their participation in the ADVICE project, Professor Christian Pfister for the stimulating and useful discussion about this topic, Professor Dario Camuffo for sending several papers referring to Italy, D) Mariano Barriendos for sending us unpublished information and data from Matute y Gaviria, Palomo and Constans, PAGES for financing a trip to a very productive meeting in Barcelona as well as the referees for their pertinent suggestions.

\section{References}

\section{Manuscripts}

Ecclesiastic sources:

Acordäos do Cabido, 1496-1762, 17 volumes (Codices Eborensis Capituit 14-IV to 14-VII).

Livros de Lembranças é Assentos, 1568-1781, 22 volumes.

\section{Individual sources:}

Castro, Joam Bast", 1766: Opusculos de Erudiçam Mixta sobre assumpto geografico. cronológico e filológico Op. $2^{\circ}$. Biblioteca Pública de Évora, Reservados, Cod. CXII/2-14.

Constans, L.G.: Una cronica inedita, p. 85, Archivo Historico Municipal de Girona.

Silva, Joseph Soares da: Gazeta composta em forma de carta, com alyumas noticias desde o anno de 1701 até o de 1704 e Noticias do anno de 1704 até o de 1716. Biblioteca Nacional, Lisboa, Reservados, Cod. 512, $303 \mathrm{f}$.

\section{Misericórdia sources:}

Livro das Lembrâças, q precipiou en 1701 e acabou em 1708 . Arquivo Distrital de Evora, Arquivo da Misericórdia de Évora. Volume 24.

Livro das Lembräçus, q precipiou em 1709 e acabou em 1719.
Arquivo Distrital de Évora, Arquivo da Misericódia de Évora. Volume 25.

Municipal sources:

Actas da Câmara Municipal de Evora. Volumes 24 to 31.

Livros da Chancelaria (Lisbon). Volumes All to A40.

Livros de Assento do Senado. Volumes B12 to B24.

Livros de Actas da Câmara Municipal de Lisboa. Volumes B25 to B.355.

\section{Books and papers}

ADVICE Final Report 1998: Part A: summary reports and appendices. Part B: ainexes.

Alcoforado, M.J. 1984: Quelques remarques sur l'évolution séculaire des précipitations à Lisbonne. In Três Estudos de Gengrafia Física, Centro de Estudos Geográficos, LAGF, Rel. 21, INIC, Lisboa, $137-69$.

Alcoforado, M.J., Nunes, F. and Garcia, J. 1997: Climat et société à Lisbonne avant la mise en place institutionnelle des observations météorologiques. Publications de l'Association Internationale de Climatologie 10, 75-83.

Barriendos, M. 1994: El Climá histórico de Cataiunya. Aproximación a sus curacteristicas generules (ss. $X V \cdots X I X)$. Unedited doctoral thesis, Department of Physical Geography, University of Barcelona.

...-... 1995: Oscilaciones climáticas seculares a través de las inundaciones catastróficas en el litoral mediterráneo: siglos XIV-XIX. Estudios Gengráficos LVI, 219, 223-37.

..-.-1997: Climatic variations in the Iberian Peninsula during the late Maunder Minimum (AD 1675-1715): an analysis of data from rogations ceremonies. The Holocene, $7,105 \cdots 11$.

Bradley, R.S. and Jones, P.D., editors 1995: Climate since AD 1500 (second edition). London: Routledge.

Brázdil, R., Dobrovolný, P., Chocholác, B. and Munzar, J. 1994: Reconstruction of the climate of Bohemia and Moravia in the period of 1615 to 1715 on the basis of written sources. In Frenzel, B., Pfister, C. and Gläser, B., eđittors, Climatic trends and anomalies in Europe 1675-1715, Stuttgart: Gustav Fischer, 109-22.

Cabral, A. Pina 1948: Memorias Históricas de 1680 a 1716. In Lisboa e seu termo, Estudos e Documentos, Associação dos Atqueólogos Portugueses, vol. II, Lisboa, 11-98.

Camuffo, D. 1987: Freezing of the Venetian Lagoon since the 9 th century $A D$ in comparison to the climate of western Europe and England. Climatic Change 10, 43--66.

Camuffo, D. and Enzi, S. 1994: The climate of Italy fiom 1675 to 1715. In Frenzel, B., Pfister, C. and Gläser, B., editors, Climatic trends and anomalies in Europe 1675-1715, Stuttgart: Gustav Fischer, 243-53.

---199: Reconstructing the climate of northern Italy from archive sources. In Bradley, R.S. and Jones, P.D)., edjtors, Climate since .10 1500, London: Routledge, 143-54.

1996: The analysis of two bi-millennial series: Tiber and Po river floods. In Jones, P.D., Bradley, R.S. and Jouzel, J., editors, Climatic variations and forcing mechanisms of the last 2000 years, NATO ASI Series, S.I., Global Environmental Change 41 , 433-50.

Eddy, J.A. 1976: The Maunder Minimum. Science 192, 173-90. Font Tullot, I. 1988: Historia del Clima de España. Cambios Climáticos y sus causas. Madrid: Instituto Nacional de Meteorologia.

Frenzel, B., Pfister, C. and Giäser, B., editors 1994: Climatic trends and anomalies in Europe 1675-1715. Stutgart: Gustay Fischer.

Frich, P. and Frydendahl, K. 1994: The summer climate in the Oresund region of Denmark, AD 1675-1715. In Frenzel, B., Pfis- 
ter, C. and Gläser, B., editors, Climatic trends and anomalies in Europe 1675-1715, Stuitgart: Gustav Fischer, 33-41.

Glaser, R. 1996: Data and methods of climatological evaluation in historical climatology. Historical Social Research 21(4), 5688.

Glaser, R., Militzer, S. and Busche, D. 1994: A contribution to the reconstruction of climate in Germany during the Late Maunder Minimum (1675 to 1715). In Frenzel, B., Pfister, C. and Gläser, B., editors, Climatic trends and anomalies in Europe 1675--171.5, Stuttgart: Gustav Fischer, 173-90.

Grove, J.M. and Conterio, A.I. 1994: Climate in the eastern Mediterranean, 1675 to 1715. In Frenzel, B., Pfister, C. and Gläser, B., editors, Climatic trends and anomalies in Europe 1675-17/5, Stuttgart: Gustav Fischer, 275-8.5.

Le Roy Ladurie, E. 1983: Histoire du climat depuis I'an mil. T II. Paris: Flammariois.

Luterbacher, J. 1998: Monthly sea level pressure patterns during the Late Maunder Minimum (1675-1715) compared with 20th century circulation. Abstracts from The Second International Climate and History Conference. CRU. University of East Anglia, 7-11 September, 3.

Luterbacher, J., Rickli, C., Tinguely, C., Xoplaki, E., Schüpbach, E., Dietrich, D., Hiisler, J., Ambühl, M., Pfister, C., Beeli, P., Dietrich, U., Dannecker, A., Davies, T.D., Jones, P.D., Slonosky, V., Ogilvie, A.E.J., Maheras, P., Kolyva-Machera, F., Martin-Vide, J., Barriendos, M., Alcoforado, M.J., Nunes, M.F., Jónsson, T., Glaser, R., Jacobeit, J., Beck, C., Philjpp, A., Beyer, U., Kaas, E., Schmith, T., Bärring, L., Iönsson, P. and Wanner, H. 2000: Reconstruction of monthly mean sea level pressure over Europe for the Late Maunder Minimum period (1675 1715) based on canonical cotrelation analysis. International Journal of Climatology, in press.

Maheras, P., Alcoforado, M.J., Giuka, S. and Vafiadis, M. 1994: Relationśs entre les périodes seches et humides des précipitations et les indices de circulation atmosphérique au Portugal durant la demière période séculaire. Publications de iAssociation Internationale de Climatologie 7, 241-48.

Maheras, P., Xoplaki, E., Davies, T.D., Martin-Vide, J., Barriendos, M. and Alcoforado, M.J. 2000: Warm and cold monihly anomalies across the Mediterranean basin and their relationshjp with circulation: 1860-1990. International Joural of Climatology, in press.

Manley, G. 1974: Central England temperatures: monthly means 1659 to 1973. Quart. J. R. Met. Soc. 100, 389-405.

Mann, M.E., Bradley, R.S. and Hughes, M.K. 1998: Globalscale temperature patterns and climate forcing over the past six centuries. Nature 392, 779-\$7.

Martin-Vide, J. and Barriendos, M. 1995: The use of rogation ceremony records in climatic reconstruction: a case sudy from Catalonia (Spain). Climatic Change 30, 201-21.

Matute y Gaviria, J. 1886: Noticias relativas a la historia de Sevilla que no constan en sus anales. Sevilla: Rasco.

Mörner, N.A. 1994: The Maunder Minimum. In Frenzel, B., Pfister, C. and Gläser, B., editors, Climatic trends and anomalies in Europe 1675-1715, Stutigart: Gustav Fischer, 1-8.

Ogilvie, A.E.J. 1995: Documentary evidence for changes in the climate of Iceland, AD 1500 to 1800 . In Bradley, R. and Jones. P., editors, Climate since AD 1500. London: Routledge, 92-117. Palomo, Francisco de B. 1984: Historia Critica de las riadas y grandes avenidas dei Guadalauivir. Colegio Oficial de Aparejadores y Aiquitectos Técnicos, Sevilla.

Peña, A.L.C. 1995: Entre la religiosidad popular y' la institucional. Las rogativas en la España Mocerna. Hispania LV/3 (191), $1027-42$.
Pfister, C. 1988: Klimageschichte der Schweiz von 1525-1860 und seine Bedeutung in der Geschichte von Bewölkerung und Landwirtschaft. Bern und Siuttgart: Verlag Paul Haupt.

-.-.-. 1992: Five centuries of Little Ice Age climate in western Europe. In Mikami, T., editor, Proceedings of the International Symposium on the Little Ice Age Climate, Tokyo: Tokyo Metropolitan University, 208--14.

- 1994a: Spatial patterns of climatic change in Europe 16751715. In Frenzel, B., Pfister, C. and Giäser, B., editors, Climatic trends and anomalies in Europe 1675-1715, Stuttgart: Gustav Fischer, 287-316.

1994b: Switzerland: The time of icy winters and chilly springs. In Frenzel, B., Pfister, C. and Gläser, B., editors, Climatic trends and anomalies in Europe 1675-1715, Stutgart: Gustav Fischer, 205-24.

...-... 1995: Monthly temperature and precipitation in Central Europe from 1525-1979: quantifying documentary evidence on wenther and its effects. In Btadley, R.S. and Jones, P., editors, Climate since $A D$ 1500, London: Routledge, 118-42.

Pfister, C. and Bareiss, W. 1994: The climate in Paris between 1675 and 1715 according to the meteorological journal of J.ouis Morin. In Frenzel, B., Pfister. C. and Gläser, B., editors, Climatic trends and anomalies in Europe 1675-1715, Stuttgart: Gustav Fischer, 151-72.

Pfister, C., Kington, J., Kleinlogel, G., Schüle and Siffert, E. 1994: High resolution spatio-temporal reconstructions of past dimate from direct meteorological observations and proxy data. In Frenzel, B., Pfister, C. and Gläser, B., editors, Climatic trends and anomalies in Europe 1675-1715, Stuttgart: Gustav Fischer, 329-75.

Rodrigo, F.S. 1996: Andalusian climate and the Maunder Minimum (1645-1715). In Obrebska-Starkel, B. and Niedzwjedz, T., editors, Proceedings of the International Conference on Climate Dynamics and Global Change Perspective, Cracow, 509-14.

Serre-Bachet, F. 1994: Annual and summer mean temperature reconstructions from tree-rings in western and southem Europe since AD 1500 with special reference to the Late Maunder Minimum. In Frenzel, B., Pfister, C. and Ciläser, B., editors, Climatic trends and anomalies in Europe 1675-1715, Stuttgart: Gusiav Fischer, 265-74.

Serre-Bachet, F., Guiot, J. and Tessier, L. 1995: Dendroclimatic evidence from southwestern Europe and northwestern Africa. In Bradley, R. and Jones, P., Climate since AD 1500, London: Routledge, 349-65.

Siegenthaler, D. 1994: Climatic trends and anomalies over the British Islands 1675 to 1715. In Frenzel, B., Pfister, C. and Gläser, B. editors, Climatic trends and anomalies in Europe 1675-1715, Stuttgart: Gustav Fischer, 133-49.

Silva, José Soares da 1931: Memórias de José Soares da Silva, Académico de Número da Academia Real da História Portuguesa. 1701-1708. Edição da Miscelânia de Oeiras.

Wanner, H., Brázdil, R., Frich, P., Frydendahl, K., Jónsson, T., Kington, J., Pfister, C., Rosenorn, S. and Wishman, E. 1994: Synoptic interpretation of monthly weather maps for the Maunder Minimum (1675-1704). In Frenzel, B., Pfister, C. and Gläser, B., editors, Climatic irends and anomalies in Europe 1675-1715, Stuttgart: Gustav Fischer, 401--24.

Wanner, H., Pfister, C., Brázdil, R., Frich, P., Frydendahl, K., Jónsson, T., Kington, J., Rosenorn, S. and Wishman, E. 1995: Wintertime European circulation patterns during the Late Maunder Minimum Cooling Period. Theoretical and Applied Climatology $5,167-75$. 